\title{
REFERENCES
}

1. Campbell, D. A., Jr., Manders, E. K., Oehler, J. R., Bonnard, G. D., Oldham, R. K., and Herberman, R. B., Cell. Immunol. 33, $364,1977$.

2. Camphell, D. A., Jr., Staal, S. P., Manders, E. K., Bonnard, G. D., Oldham, R. K., Salzman, L. A., and Herberman, R. B., Cell. Immunol. 33, 378, 1977.

3. Bonmassar, E., Bonmassar, A., Golden, U., and Cudkowicz, G., Cancer Res. 33, 1054, 1973.

4. Bonnard, G. D., Manders, E. K., Campbell, D. A., Jr., Herberman, R. B., and Collins, M. J., J. Exp. Med. 143, 187, 1976.

5. Fortner, G. W., Kuperman, O., and Lucas, Z. J., J. Immunol. 115, 1269, 1975.

6. Kuperman, O., Fortner, G. W., and Lucas, Z. J. J. Immunol. 115, 1277, 1975.

7. Kuperman, O., Fortner, G. W., and Lucas, Z. J., J. Immunol. 115, 1282, 1975.

8. Huber, S. A., and Lucas, Z. J., J. Immunol. 119, 726, 1977.

9. Huber, S. A., Walker, S. M., and Lucas, Z. J., submitted to J. Immunol. Methods, 1977.

10. Huber, S. A., and Lucas, Z. J., submitted to J. Immunol, Methods, 1977.

\section{Reply to: Letter to the Editor}

\section{To the Editor:}

Whether or not a virus is present in a tumor cell preparation is an important consideration in the interpretation of in vitro tests of cellular immunity. We do not at present know whether infection of our 13762 mammary adenocarcinoma line with Kilham Rat Virus (KRV) has any relevance to host resistance to the tumor in vivo. The data presented by Huber and Lucas do not completely obviate the presence of KRV in their system for a number of reasons. First and most importantly, the stimulating cells used by these authors in MLTR assays were not, as we have used, in vivo passaged cells, but were instead tissue culture adapted monolayer cells, carried within the sterile confines of an incubator. These cells may well differ from the ascites preparation with respect to the presence of the virus. If ascites passaged cells are used for inoculation of animals for in vivo studies, as is often the case, conclusions about the tumorigenicity of the ascites preparation, and the influence KRV has on tumorigenicity, cannot be based on in vitro tests done with tissue culture adapted cells. Secondly, evidence for the viral infection in vitro, in our hands, usually depended on high levels of cellular turnover, a fact in keeping with the known dependence of this virus on a rapid cellular turnover. Levels of PHA stimulation presented by Huber and Lucas in their letter were far lower $(10,000 \mathrm{cpm})$ than the usual levels we generated with PHA (25-50,000). Lastly, evidence for viral inhibition in our system also depended on somewhat longer incubation times (3-5 days) than were used by Huber and Lucas in their PHA assay (2 days).

Huber and Lucas have been considerably more successful than ourselves in demonstrating an immune response to this interesting model. Such success may be related to the absence of KRV infection in the tumor cells studied. However, a final conclusion about the influence KRV has on tumorigenicity and immunogenicity in this system should rest on a direct serological assay for the virus in both ascites passaged and tissue culture adapted cells being investigated.

\author{
Sincerely, \\ D. A. CAMPBELL, JR., M.D. \\ Department of Surgery, University of Michigan Medical Center \\ Ron ald B. Herberman, M.D. \\ Laboratory of Immunodiagnosis National Institutes of Health
}

